\title{
Guanylate cyclase C limits systemic dissemination of a murine enteric pathogen
}

\author{
Elizabeth A Mann², Eleana Harmel-Laws², Mitchell B Cohen ${ }^{1,2}$ and Kris A Steinbrecher ${ }^{1,2^{*}}$
}

\begin{abstract}
Background: Guanylate Cyclase C (GC-C) is an apically-oriented transmembrane receptor that is expressed on epithelial cells of the intestine. Activation of GC-C by the endogenous ligands guanylin or uroguanylin elevates intracellular CGMP and is implicated in intestinal ion secretion, cell proliferation, apoptosis, intestinal barrier function, as well as the susceptibility of the intestine to inflammation. Our aim was to determine if GC-C is required for host defense during infection by the murine enteric pathogen Citrobacter rodentium of the family Enterobacteriacea.

Methods: $\mathrm{GC}-\mathrm{C}^{+/+}$control mice or those having GC-C genetically ablated $\left(\mathrm{GC}-\mathrm{C}^{-/-}\right)$were administered $\mathrm{C}$. rodentium by orogastric gavage and analyzed at multiple time points up to post-infection day 20. Commensal bacteria were characterized in uninfected $\mathrm{GC}-\mathrm{C}^{+/+}$and $\mathrm{GC}-\mathrm{C}^{-/-}$mice using $16 \mathrm{~S}$ rRNA PCR analysis.

Results: $\mathrm{GC}-\mathrm{C}^{-/-}$mice had an increase in $\mathrm{C}$. rodentium bacterial load in stool relative to $\mathrm{GC}-\mathrm{C}^{+/+}$. C. rodentium infection strongly decreased guanylin expression in $\mathrm{GC}-\mathrm{C}^{+/+}$mice and, to an even greater degree, in $\mathrm{GC}-\mathrm{C}^{-/-}$ animals. Fluorescent tracer studies indicated that mice lacking GC-C, unlike GC-C ${ }^{+/+}$animals, had a substantial loss of intestinal barrier function early in the course of infection. Epithelial cell apoptosis was significantly increased in GC- $C^{-1-}$ mice following 10 days of infection and this was associated with increased frequency and numbers of $C$. rodentium translocation out of the intestine. Infection led to significant liver histopathology in $\mathrm{GC}-\mathrm{C}^{-/-}$mice as well as lymphocyte infiltration and elevated cytokine and chemokine expression. Relative to naïve $\mathrm{GC}-\mathrm{C}^{+/+}$mice, the commensal microflora load in uninfected $\mathrm{GC}-\mathrm{C}^{-1-}$ mice was decreased and bacterial composition was imbalanced and included outgrowth of the Enterobacteriacea family.
\end{abstract}

Conclusions: This work demonstrates the novel finding that GC-C signaling is an essential component of host defense during murine enteric infection by reducing bacterial load and preventing systemic dissemination of attaching/effacing-lesion forming bacterial pathogens such as C. rodentium.

Keywords: Guanylate cyclase, Guanylyl cyclase, cGMP, Intestine, Colon, Attaching and effacing lesion, Epithelial cell apoptosis, Intestinal barrier function

\section{Background}

Citrobacter rodentium (C. rodentium) are gram-negative bacteria of the family Enterobacteriaceae, and are natural enteric pathogens of mice. Related family members, enteropathogenic Escherichia coli (EPEC) and enterohemorrhagic E. coli (EHEC), are human pathogens that are a major cause of infectious diarrhea worldwide. Similar to these bacteria,

\footnotetext{
*Correspondence: Kris.Steinbrecher@cchmc.org

${ }^{1}$ Department of Pediatrics, University of Cincinnati College of Medicine, Cincinnati, OH, USA

${ }^{2}$ Division of Gastroenterology, Hepatology, and Nutrition, Cincinnati Children's Hospital Medical Center, 3333 Burnet Ave, MLC 2010, 45229

Cincinnati, $\mathrm{OH}, \mathrm{USA}$
}

lesion-forming pathogens carry a set of virulence genes termed the locus of enterocyte effacement which enable close association with the apical membrane of intestinal cells, causing local destruction of microvilli and transfer of effector gene products via a type III secretion system [1]. In $\mathrm{C} 57 \mathrm{BL} / 6$ mice and other strains that are considered resistant to $C$. rodentium, colonization results in a self-limiting infection which is cleared by both the innate and the adaptive immune systems. The course of infection is characterized by intestinal epithelial cell apoptosis, infiltration of inflammatory cells, mainly macrophage and neutrophils, and crypt hyperplasia, all of which are largely resolved within 3 weeks. In contrast, susceptible

\section{Biomed Central}

(c) 2013 Mann et al.; licensee BioMed Central Ltd. This is an Open Access article distributed under the terms of the Creative Commons Attribution License (http://creativecommons.org/licenses/by/2.0), which permits unrestricted use, distribution, and reproduction in any medium, provided the original work is properly cited. 
strains exhibit severe, often fatal, diarrhea which has been attributed at least in part to decreased expression of transporters important in chloride ion homeostasis [2] and to differences in the intestinal microbiota [3,4].

Guanylate cyclase $2 \mathrm{C}$ (encoded by Gucy2c, hereafter termed $\mathrm{GC}-\mathrm{C}$ ) is a transmembrane receptor present in the intestine which, in concert with its ligands guanylin (GN, encoded by Guca2a,) [5] and uroguanylin (UGN, encoded by Guca2b) [6], is known to regulate both chloride/bicarbonate ion secretion (via the cystic fibrosis transmembrane conductance regulator, CFTR) $[7,8]$ and sodium absorption (via the $\mathrm{Na}^{+} / \mathrm{H}^{+}$exchanger 3, NHE3, Slc9a3) [9]. The first step in this regulatory cascade is ligand activation of $\mathrm{GC}-\mathrm{C}$ to generate the second messenger cyclic guanosine monophosphate (cGMP). Some strains of infectious enterotoxigenic $E$. coli produce the heat-stable enterotoxin, ST, which acts as a GC-C superagonist [10]. Unlike activation of $\mathrm{GC}-\mathrm{C}$ by the endogenous ligands GN or UGN, robust overproduction of cGMP by ST-bound GC-C deregulates downstream signaling pathways and causes secretory diarrhea. Mice carrying a targeted disruption of Gucy $2 c$ have reduced levels of intestinal cGMP, and are resistant to ST $[11,12]$. Importantly, further studies of Gucy2c knockout (hereafter called $\mathrm{GC}-\mathrm{C}^{-/-}$) mice have provided evidence for actions of $\mathrm{GC}-\mathrm{C}$ beyond fluid and ion homeostasis in the gut. Signaling via GC-C has been implicated in intestinal epithelial cell cycle regulation, apoptosis, and progression to gastrointestinal cancer [13-15]. More recently, we have shown the presence of a defective intestinal epithelial barrier as well as sensitivity to DNA damage-induced cell death in mice lacking GC-C $[16,17]$. In a model of chemical-induced intestinal injury, $\mathrm{GC}^{-\mathrm{C}^{-/-}}$ mice exhibited a blunted intestinal inflammatory response that was accompanied by reduced cytokine expression [18]. Based on these findings, we utilized the $C$. rodentium model of enteric bacterial pathogen infection to investigate the hypothesis that GC-C effector pathways are an important aspect of host defense in the intestinal mucosa.

\section{Methods}

\section{Mice}

GC- $\mathrm{C}^{-/-}$mice carrying a targeted deletion of Gucy2c, the gene encoding $\mathrm{GC}-\mathrm{C}$, have previously been described by us [11]. Heterozygous $\mathrm{GC}^{-\mathrm{C}^{+/-}}$mice have been back-crossed to the C57BL/6 J strain (Jackson Laboratory,

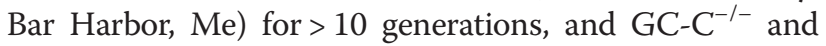
$\mathrm{GC}^{-\mathrm{C}^{+/+}}$mouse lines were generated by this process. As in our recent work $[16,18]$, both $\mathrm{GC}-\mathrm{C}^{+/+}$and $\mathrm{GC}-\mathrm{C}^{-/-}$ mouse lines were maintained in the same room of our animal facility under identical specific-pathogen free conditions. Mice of both sexes, aged 6-12 weeks were used, and experiments were performed on age- and gender- matched groups. All studies were approved by the Cincinnati Children's Hospital Medical Center Institutional Animal Care and Use Committee.

\section{C. rodentium infection of mice}

C. rodentium bacteria from frozen stocks of strain DBS 100 (gift of Philip M. Sherman, Hospital for Sick Children, Toronto, Canada) were grown on MacConkey's agar (Becton, Dickinson and Company, Sparks, MD) overnight at $37^{\circ} \mathrm{C}$. A single colony was then cultured in Luria-Bertani broth overnight at $37^{\circ} \mathrm{C}$. We used optical density measurements at $600 \mathrm{~nm}$ to assess the concentration of bacteria, and confirmed colony forming units (CFU) by plating serial dilutions on MacConkey's agar. Within each study, groups of $\mathrm{GC}-\mathrm{C}^{+/+}$and $\mathrm{GC}-\mathrm{C}^{-/-}$mice with free access to food and water were infected by oral gavage with the same freshly prepared mixture of $\mathrm{C}$. rodentium $\left(\sim 1.5 \times 10^{9} \mathrm{CFU} C\right.$. rodentium in $100 \mu \mathrm{l}$ sterile PBS per mouse). Stool from individual mice was collected and weighed every few days after gavage, beginning at day 4. To determine bacterial burden, stool was homogenized in sterile PBS (0.1 g stool/1 ml PBS) and serial dilutions were plated on MacConkey's agar. Colonies were counted after overnight incubation at $37^{\circ} \mathrm{C}$. The limit of detection was $5 \times 10^{2} \mathrm{CFU} / \mathrm{g}$ stool. A mouse was excluded from further analysis if the level of $C$. rodentium was below the limit of detection at 4 days post-infection. PCR analysis of the $C$. rodentium esp $B$ gene was performed on representative colonies to confirm identity.

\section{Analysis of $C$. rodentium infected mice}

Groups of mice were sacrificed at 4, 10, and 20 days after infection. Colon, feces, and liver were aseptically removed. A caudal piece $(0.5 \mathrm{~cm})$ of the distal colon was frozen in liquid nitrogen for subsequent RNA extraction, while the remaining section was split longitudinally into "swiss rolls" for formalin fixation/paraffin embedding and for frozen OCT embedding. Sections of liver were frozen in liquid nitrogen for RNA analysis or fixed in formalin/paraffin for histology. In addition, liver sections (trimmed to $0.1 \mathrm{~g}$ weight) were homogenized in $1 \mathrm{ml}$ of sterile PBS, and plated on MacConkey's agar. C. rodentium colonies were counted after incubation at $37^{\circ} \mathrm{C}$ overnight. The limit of detection for liver homogenates was $40 \mathrm{CFU} / \mathrm{g}$ and identity was confirmed by PCR analysis performed as above. Tissues from additional naïve (non-infected) age- and gender-matched mice were similarly obtained and processed.

\section{Histology, immunofluorescence and immunoblotting}

$\mathrm{H} \& \mathrm{E}$ staining of intestinal and hepatic sections was done using standard techniques as previously described $[18,19]$. Images were obtained on an Olympus BX51 microscope equipped with an Olympus DP71 camera and DP Manager 
software. Measurements of crypt depth were taken on micrographs of all well-oriented crypts from H\&E-stained "swiss roll" sections of distal colon using ImageJ version 1.38 (National Institutes of Health, Bethesda, MD). Stained slides (distal colon) were also examined to assess colitis severity in terms of disease scores composed of the degree of inflammation, hyperplasia, and infiltrate composition using a modified scoring system based on previous studies $[18,20,21]$. Briefly, this system assessed inflammation (scored $0-4$ where 0 is no inflammation and 4 is severe ulceration and crypt abscess), hyperplasia ( $0-3$ where 0 is no hyperplasia and 3 is severe hyperplasia with mucin depletion), and inflammatory composition $(0-3$ where 0 is none and 3 is substantial mononuclear cells with high neutrophil content). C. rodentium was localized in the distal colon by incubating OCT frozen sections with anti-E. coli Polyvalent 8 LPS antibody (1:500, Denka Seiken Co., Tokyo, Japan) as according to protocol and helpful advice from Dr. Bruce Vallance (University of British Colombia, Canada) [22]. Sections were then incubated with anti-swine CF-488A-conjugated IgG secondary antibody (1:2000, Sigma-Aldrich Corp., St. Louis, MO) and counter-stained with DAPI. Apoptosis was quantitated via immunofluorescence with cleaved caspase 3 antibody (CC3, antibody \#9661, Cell Signaling Technology, Inc., Danvers, MA) as performed previously on OCT frozen sections $[19,23]$. Positive-stained intestinal epithelial cells were tabulated from 8-12 micrograph fields (original magnification 200x) per mouse. Immunofluorescence of E-cadherin (\#13-1900, Life Technologies; Carlsbad, CA), claudin 2 (\#51-6100, Life Technologies) and claudin 3 (\#341700, Life Technologies) was performed on frozen sections in a similar manner. Tubulin, claudin 2, and claudin 3 immunoblotting was performed as previously described on extracts from homogenized colon.

\section{Real-time RT-PCR}

Total RNA was isolated from frozen tissue using Tri Reagent (Molecular Research Center, Inc., Cincinnati, $\mathrm{OH}$ ) according to the manufacturer's protocol. Integrity of the RNA was verified by visualization of $28 \mathrm{~S}$ and $18 \mathrm{~S}$ RNA after gel electrophoresis. Following cDNA preparation (starting quantity of $2.5 \mathrm{ug}$ RNA) with random hexamers (Verso cDNA kit, Thermo Fisher Scientific, Inc., ABgene House, Epsom, UK), real-time PCR reactions using genespecific primers were performed with Brilliant II SYBR Green QPCR mix (Stratagene, La Jolla, CA) in the Mx3000p thermocycler (Stratagene). Primer sequences for GC-C [24], NHE3 [25], and CXCL1 [19] and LBP [26] have been published previously. Additional primer sequences used in this report are given in Table 1. Values were normalized to expression of glyceraldehyde-3-phosphate dehydrogenase (GAPDH), and the average fold increase relative to the average level in gender-matched
Table 1 Real time RT-PCR primers

\begin{tabular}{|c|c|}
\hline Primers & Sequences \\
\hline \multirow[t]{2}{*}{ Gn } & For 5'- CAC TGT GCA GGA TGG AGA C-3' \\
\hline & Rev 5'-CTC GGC GTT GGG TाT CT-3' \\
\hline \multirow[t]{2}{*}{ CFTR } & For 5'-GCA CAG CAG CTC AAA CAA CTG GAA-3' \\
\hline & Rev 5'-TTC TCA TाT GGA ACC AGC GCA AGC-3' \\
\hline \multirow[t]{2}{*}{$\mathrm{IL}-22$} & For 5'-AAA CTG TTC CGA GGA GTC AGT GCT \\
\hline & Rev 5'-GCT GAG CTG ATT GCT GAG TाT GGT-3' \\
\hline \multirow[t]{2}{*}{ CXCL9 } & For 5'-TTT CAT CAC GCC CTT GAG CCT AGT-3' \\
\hline & Rev 5'-TाT GGT GAC GTG AGC CTC AGA AGT-3' \\
\hline \multirow[t]{2}{*}{ GAPDH } & For 5'-ACC ACA GTC CAT GCC ATC AC-3' \\
\hline & $\overline{R e v} 5^{\prime}$-TCC ACC ACC CTG TTG CTG TA-3' \\
\hline
\end{tabular}

naïve mice was calculated using the comparative threshold cycle method $(\Delta \Delta \mathrm{Ct})$.

\section{Measurement of intestinal permeability}

Intestinal permeability was assessed by measuring movement of a fluorescent tracer (4 kDa FITC-dextran, Sigma-Aldrich, St. Louis, MO) from the gut lumen to the blood. Uninfected and day $4 \mathrm{C}$. rodentium infected mice of both $\mathrm{GC}-\mathrm{C}^{+/+}$and $\mathrm{GC}-\mathrm{C}^{-/-}$genotypes were orally gavaged with $200 \mathrm{ul}$ of $70 \mathrm{mg} / \mathrm{ml}$ FITC-dextran dissolved in water. Mice were given FITC-dextran solution four hours prior to blood collection at sacrifice. Serum samples were diluted and read in a 96 well plate at 485 excitation/535 emission along with a FITC-dextran standard curve. The calculated serum concentration of FITC-dextran was interpreted as an indication of intestinal permeability.

\section{Bacterial DNA and quantitative PCR analysis}

Bacterial DNA was isolated with the QIAamp DNA Stool Mini Kit (QIAGEN, Valencia, CA) according to manufacturer's instructions for pathogen DNA, including the optional $95^{\circ} \mathrm{C}$ incubation step. Stool from individual adult mice was weighed, frozen at $-80^{\circ} \mathrm{C}$, and homogenized directly in ASL lysis buffer (QIAGEN) prior to DNA extraction. Genomic DNA from cultures of the laboratory Escherichia coli strain, DH5 2 , was also prepared using this kit. Integrity of DNA was checked by agarose gel electrophoresis, and the concentration determined using the Quant-iT dsDNA Broad-Range Assay Kit (Invitrogen, Molecular Probes, Inc., Eugene, OR). To quantify bacteria, real-time PCR was performed using Brilliant II SYBR Green QPCR mix (Stratagene) and published sets of group- or family-specific $16 \mathrm{~S}$ ribosomal RNA (rRNA) gene primers as follows: Eubacterium rectales/Clostridiae cocoides [27], Enterobacteriacea [27], Atopobium [28] Lactobacillus [28], Bacteroides-Prevotella-Porphyromonas [28] and Bifidobacteria [28]. For determining total bacterial load, universal 16S rRNA gene primers that recognize all 
eubacteria were used [27]. A standard curve of serial dilutions of a known amount of DH5 $\alpha$ DNA was generated, and used to interpolate the quantity of bacteria from each experimental DNA sample. To assess the relative quantity of each group the $\Delta \mathrm{Ct}$ method was used with normalization by total bacteria values [29].

\section{Data analysis}

Categorical variables were evaluated by Fisher exact test. Differences in continuous variables were compared using the Mann-Whitney test or 2-tailed Student $t$ test. For all analyses, statistical significance was set at $P \leq 0.05$ and was determined using Prism Version 5.03 (GraphPad Software, Inc., San Diego, CA).

\section{Results}

Mice lacking GC-C exhibit increased load of $C$. rodentium but retain the ability to clear the infection

Mice were infected with $C$. rodentium $\left(1.5 \times 10^{9} \mathrm{CFU}\right)$ by oral gavage. Colonization was monitored by stool culture beginning at 4 days post-infection (p.i.). The results from several experiments are summarized in Figure 1A. For both genotypes the number of $C$. rodentium $\mathrm{CFU}$ recovered from stool varied widely at 4 days p.i., rose to a plateau between days 10 and 14, and then declined to the lower limit of detection by day 20. This is similar to the time course for infection in C57BL/6 mice previously reported in the literature $[30,31]$. There was a strong trend toward increased $C$. rodentium load in $\mathrm{GC}-\mathrm{C}^{-/-}$mice by 4 days p.i. but this narrowly missed statistical significance $(P=0.07)$. At 10 days p.i., the median number of $C$. rodentium present in the stool of $\mathrm{GC}^{-\mathrm{C}^{-/}}$mice was 8 times

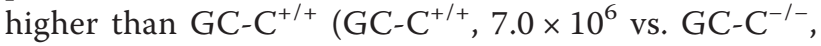
$5.5 \times 10^{7} \mathrm{CFU} / \mathrm{g}$ stool, $P \leq 0.02$ ). This was not the case during the latter stages of the infection course when adaptive immunity typically reduces $C$. rodentium numbers and eventually clears the pathogen. We used immunofluoresent staining with antibodies reactive to C. rodentium lipopolysaccharide (LPS) to localize the bacteria in distal colon tissue sections at days 4 (data not shown) and 10 p.i. (Figure 1B). At both time points, there was no difference in localization of the pathogen as there was apparent staining at the epithelial cell surface of both genotypes. There were also occasional crypts that exhibited staining along the upper crypt epithelium in both genotypes.

Mice of the C57BL/6 J genetic background do not respond to $C$. rodentium infection with grossly obvious clinical symptoms such as weight loss or diarrhea $[2,32]$. As expected, we found this to be the case in $\mathrm{GC}-\mathrm{C}^{+/+}$ mice and, in fact, there were no symptoms of diarrhea or loss of body weight in $\mathrm{GC}-\mathrm{C}^{-/-}$mice as well (data not shown). Real-time RT- PCR analysis showed that the level

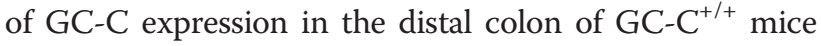
was modestly elevated at 10 p.i. (Figure 2). Production of
GN, the most abundant colonic ligand of GC-C, was substantially decreased beginning at day 4 of infection in both genotypes, although this was significantly greater in infected GC-C $\mathrm{C}^{-/-}$mice relative to infected wildtype animals. It was notable that loss of $\mathrm{Gn}$ expression begins at infection day 4, prior to the pronounced epithelial hyperplasia or goblet cell loss typically seen by us and others in C. rodentium infected mice at later disease time points. GC-C generates cGMP that in turn controls the activity of several epithelial ion transporters, many of which are transcriptionally regulated during $C$. rodentium infection $[32,33]$. CFTR chloride channel mRNA increased at day 10 p.i. in mice of both genotypes compared to uninfected mice while there was no difference in expression of the $\mathrm{Na}^{+} / \mathrm{H}^{+}$exchanger NHE3 (Figure 2).

\section{Epithelial hyperplasia during C. rodentium infection is not affected by deletion of $\mathrm{GC}-\mathrm{C}^{-/-}$}

Bacterial pathogen infection of the colon is often associated with a derangement in epithelial homeostasis as reflected by altered crypt architecture and cell death. For example, crypt hyperplasia is a hallmark of the host response to cell death and inflammation caused by $C$. rodentium infection [34]. Histological examination of C. rodentium infected mice at day 10 p.i. revealed significant epithelial hyperplasia in both GC-C ${ }^{+/+}$and GC-C ${ }^{-/-}$mice (Figure 3A). Marked inflammation and immune cell infiltrate were also apparent in both genotypes and was not affected by the absence of GC-C (histologic disease score for $\mathrm{GC}^{-\mathrm{C}^{+/+}}, 5.2 \pm 0.8$ vs. $\mathrm{GC}^{-\mathrm{C}^{-/-}}, 6.0 \pm 0.7$, mean with $\mathrm{SE}, \mathrm{n}=12$ mice per group, $P=0.49$, Student $\mathrm{t}$ test). Depth measurements were taken in well-oriented crypt sections from the distal colon of naive and day 10 infected mice (Figure 3B). A modest but significant increase in crypt depth was found in naive GC-C ${ }^{-1-}$ distal colon compared to wild type $(164 \pm 1.67 \mu \mathrm{m}$ vs. $146 \pm 1.92 \mu \mathrm{m}$, mean \pm SEM, $P \leq 0.0001)$. This is in agreement with earlier studies by us and others showing increased crypt depth in the colon of mice lacking GC-C or GC-C-activating ligands such as GN $[35,13]$. C. rodentium infection significantly increased crypt depth in both genotypes as measured at day 10 p.i. However, no significant difference in colonic crypt depth between infected $\mathrm{GC}^{-\mathrm{C}^{+/+}}(219 \pm 2.09 \mu \mathrm{m})$ and infected $\mathrm{GC}-\mathrm{C}^{-/-}$ $(216 \pm 1.61 \mu \mathrm{m})$ mice was detected.

\section{GC-C regulates colonic epithelial apoptosis during bacterial pathogen infection}

We have previously shown that GC-C activity plays an important role in regulating epithelial apoptosis during radiation and chemical challenge $[17,18]$. C. rodentium infection is associated with increased epithelial cell death in the intestine [1]. Therefore, we quantitated staining of epithelial cleaved caspase 3 as a marker of apoptosis in colonic sections from naïve, day 4 , and day 10 

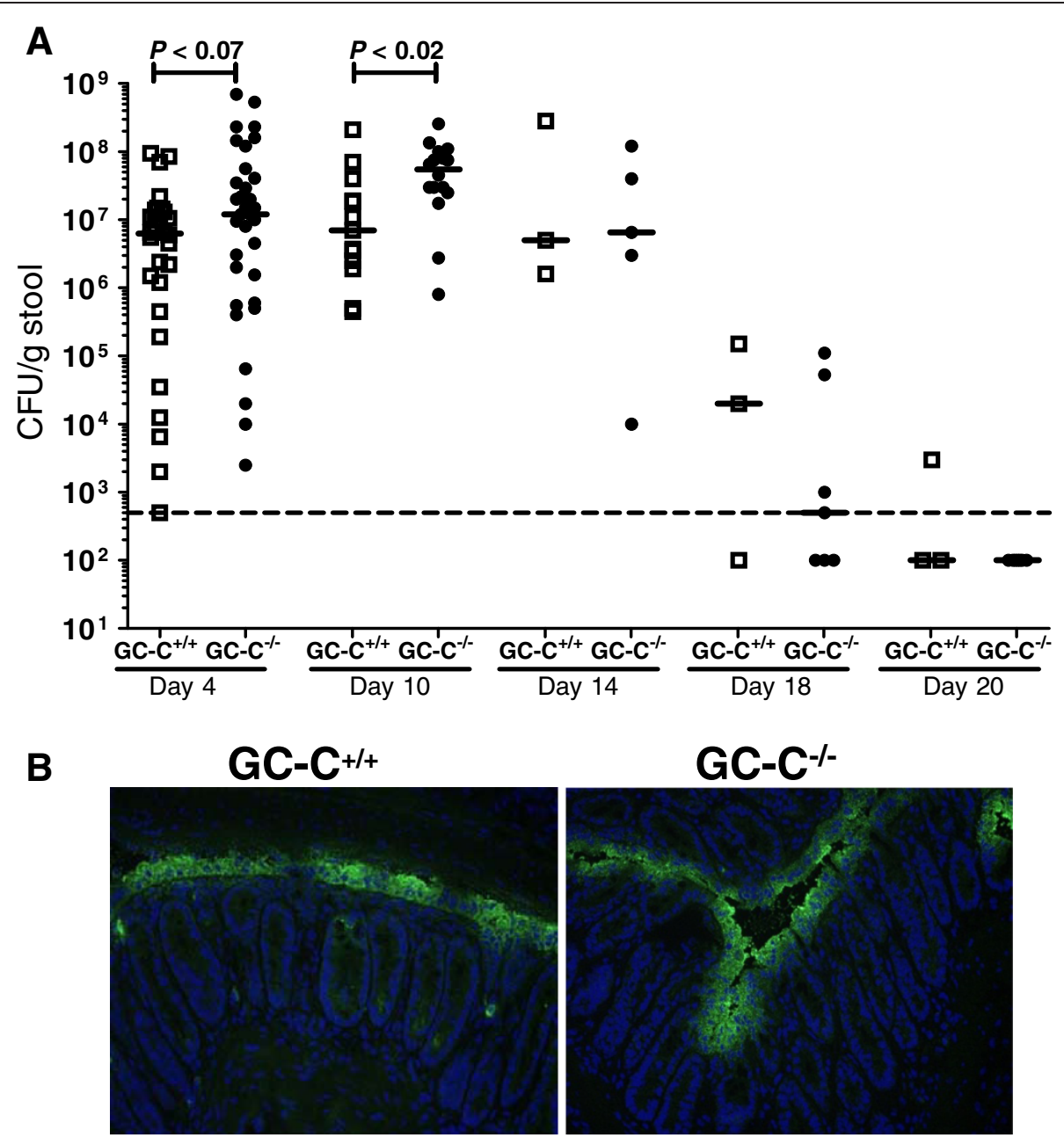

Figure $1 \mathrm{GC}^{-\mathrm{C}^{-/-}}$mice have an increased load of $\mathrm{C}$. rodentium compared to $\mathrm{GC}-\mathrm{C}^{+/+}$but are still able to clear the infection. A: Increasing numbers of $C$. rodentium were detected in stool from $\mathrm{GC}-\mathrm{C}^{-/}$mice such that by day 10 there were significantly greater numbers of $C$. rodentium present relative to $\mathrm{GC}-\mathrm{C}^{+/+}$. Note that both genotypes were able to clear the infection by day 20. Each time point consisted of groups of 3-26 mice. Solid line represents median value. Dotted line indicates limit of detection (500 CFU/g stool). Samples below limit of detection were arbitrarily given a value of 100. B: Representative photomicrographs of sections of distal colon of infected GC- $\mathrm{C}^{-/-}$and $\mathrm{GC}-\mathrm{C}^{+/+}$mice labeled with LPS specific antibody (green) exhibit similar bacterial localization at day 10 p.i. Images were counterstained with DAPI (blue). Original magnification was 400X.

infected mice. As expected, there was a similar, low level of cell death in naïve $\mathrm{GC}-\mathrm{C}^{+/+}$and $\mathrm{GC}-\mathrm{C}^{-/-}$colon (Figure 4A). While there was only a minimal increase in $C$. rodentium infected mice of either genotype at day 4 p.i., cleaved caspase 3 staining was highly elevated at day 10 p.i. in $\mathrm{GC}-\mathrm{C}^{-/-}$mice as compared to wildtype controls. Notably, widespread and pervasive epithelial cell death in $\mathrm{GC}^{-\mathrm{C}^{-/}}$colon was apparent. Quantitation of cleaved caspase 3-positive epithelial cells demonstrated

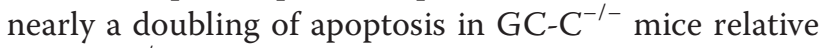
to $\mathrm{GC}-\mathrm{C}^{+/+}$animals at day 10 p.i. (Figure $4 \mathrm{~B}$ ). These data clearly indicate that GC-C is essential for epithelial cell resistance to cell death induced by attaching and effacing lesion forming bacteria.

\section{Citrobacter infection induces barrier dysfunction} in the absence of GC-C

In the context of $C$. rodentium infection, increased hyperplasia and cell death at the height of infection ( $\sim$ day 10 p.i.), such as that measured in $\mathrm{GC}-\mathrm{C}^{+/+}$and $\mathrm{GC}-\mathrm{C}^{-/-}$mice, can enhance epithelial permeability. Previous work by us and others indicates that GC-C may be important in regulating intestinal barrier function as its deletion correlates with loss of epithelial tight junction stability in the bowel $[16,36]$. Therefore, we hypothesized that subtle defects in colonic barrier function may be apparent in $\mathrm{GC}-\mathrm{C}^{-/-}$mice early in the course of $C$. rodentium infection, prior to the widespread epithelial damage present by day 10 p.i. In order to track potential movement of luminal 


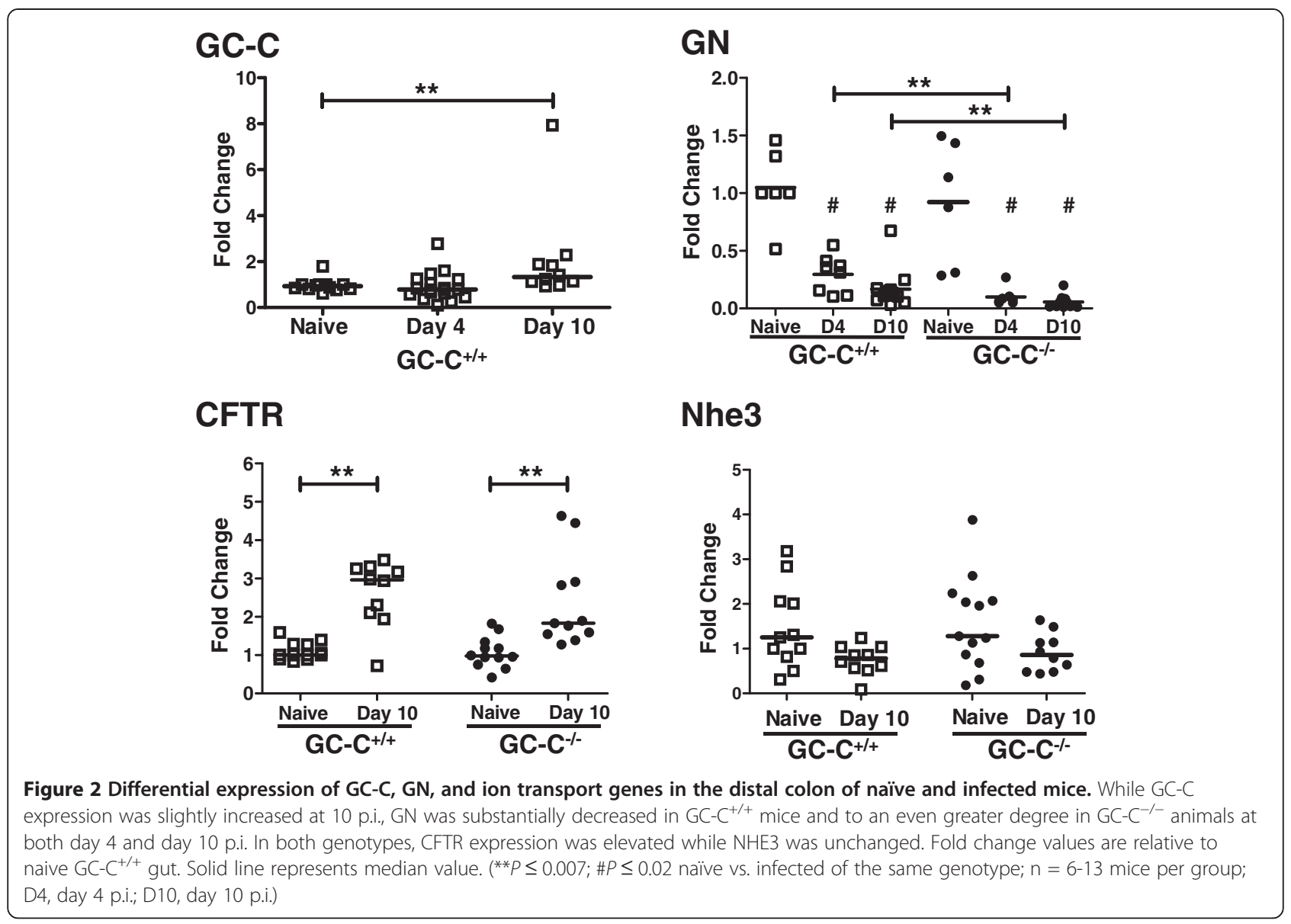

contents through the epithelial cell layer and into the serosal compartment, we orally gavaged uninfected and day 4 p.i. GC-C $\mathrm{C}^{+/+}$and $\mathrm{GC}-\mathrm{C}^{-/-}$mice with a $4 \mathrm{kDa}$ fluorescent tracer (FITC-dextran) four hours prior to necropsy. Unlike GC- $\mathrm{C}^{+/+}$mice, animals lacking GC-C had a substantial loss of barrier function following 4 days of $C$. rodentium infection as indicated by increased serum

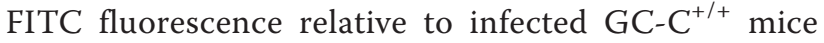
(Figure 5A). Claudin proteins are essential for tight junction stability and loss of specific claudin isoforms is associated with barrier dysfunction during C. rodentium infection [16,36-38]. Therefore, we selected two relevant claudin proteins, claudins 2 and 3 , and determined their localization and expression levels in C. rodentium-infected wildtype and $\mathrm{GC}-\mathrm{C}^{-/-}$mice at day 4 p.i. Colonic sections (Figure 5B), counter-stained with E-cadherin and DAPI, showed no genotype-dependent differences in cell membrane localization of either claudin 2 or claudin 3. Furthermore, immunoblotting demonstrated that each was present in similar quantities within the colon of ${\mathrm{GC}-\mathrm{C}^{+/+}}$and GC-C ${ }^{-1-}$ mice (Figure $5 \mathrm{C}$ ). Collectively, these data demonstrate that GC-C is essential for preserving colonic barrier function beginning at the earliest stages of enteric bacterial infection but that additional studies will be necessary to define the molecular mechanisms that drive this loss of function in $\mathrm{GC}-\mathrm{C}^{-/-}$mice.

\section{GC-C limits systemic dissemination of $C$. rodentium}

A low level of bacterial translocation from the intestine to the blood, liver, and other organs occurs during the course of experimental C. rodentium infection $[39,40]$. The barrier dysfunction and increased apoptosis found in $\mathrm{GC}^{-\mathrm{C}^{-/-}}$mice during infection suggested that these mice may fail to sequester the pathogen in the intestine. We therefore assessed $C$. rodentium translocation out of the intestine by plating liver homogenates from colonized mice on MacConkey's agar. At 4 days p.i., no live bacteria were detected in homogenized liver from either genotype. However, by day 10 p.i. there were significantly more GC- $\mathrm{C}^{-/-}$mice that exhibited colony growth: 31\% (4/13) of $\mathrm{GC}^{-\mathrm{C}^{+/+}}$livers were positive for $C$. rodentium compared to $88 \%(14 / 16)$ of $\mathrm{GC}^{-C^{-1-}}$ livers $(P \leq 0.003$, Fisher's exact test). The number of colony forming units of $C$. rodentium recovered from day 10 p.i. liver samples was also significantly increased in mice lacking GC-C (Figure 6A). By day 20 , colonies were no longer detectable from livers of GC-C $\mathrm{C}^{-/-}$mice, consistent with the time course of bacterial clearance from the stool. 


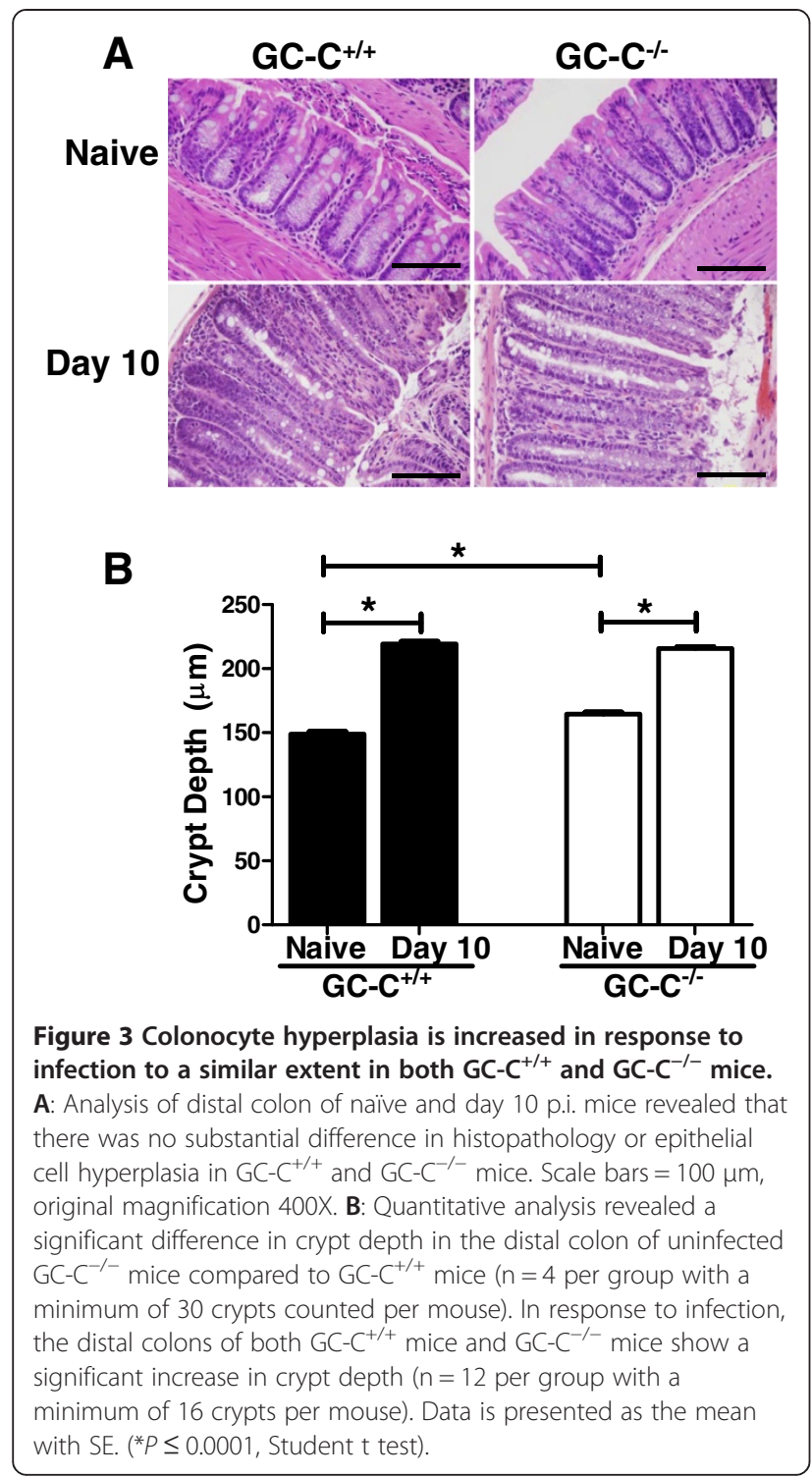

We next performed a histological survey of liver tissue from wildtype and $\mathrm{GC}-\mathrm{C}^{-1-}$ mice. Day 4 p.i. liver histology revealed mild inflammatory infiltrate with no indication of increased severity in $\mathrm{GC}-\mathrm{C}^{-/-}$mice as compared to $\mathrm{GC}^{-\mathrm{C}^{+/+}}$animals (data not shown). Consistent with a lack of intestinal containment of $C$. rodentium, focal areas of necrosis at day 10 p.i., were noted in the liver of $\mathrm{GC}-\mathrm{C}^{-/-}$ mice upon necropsy whereas none could be seen in the livers of any mice of the GC- $\mathrm{C}^{+/+}$group (Figure 6B). This damage was apparent histologically as well, and included multiple areas of inflammatory infiltrate visible upon microscopic examination of $\mathrm{GC}^{-\mathrm{C}^{-/-}}$liver sections (Figure 6C).

Our analysis then focused on gene expression in livers of mice infected with C. rodentium with the expectation that inflammation in $\mathrm{GC}^{-\mathrm{C}^{-/}}$mice would coincide with

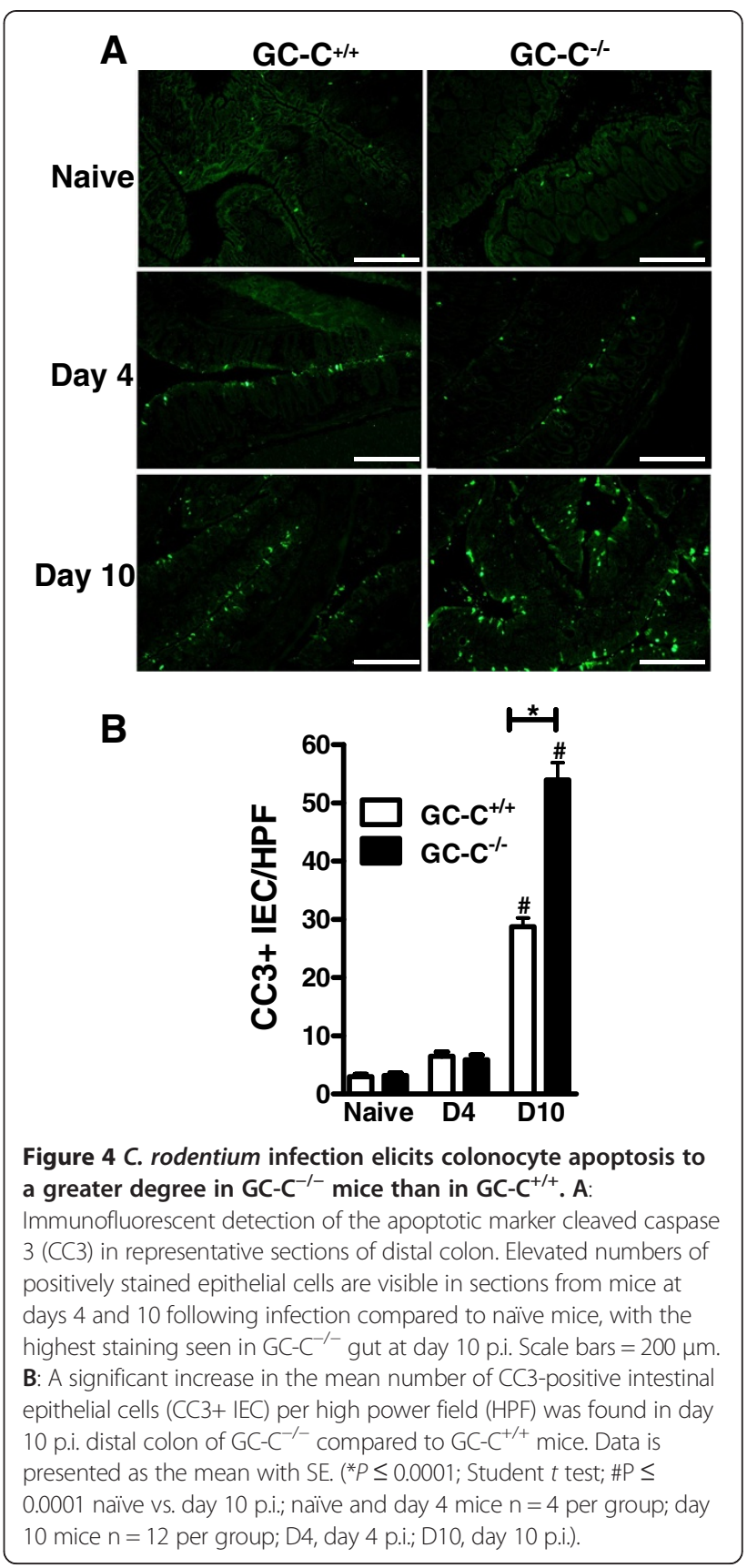

elevated activation of pro-inflammatory genes. Relative to naive mice, we found that there was increased liver expression of inflammatory cytokines and chemo-attractants such as IL-22, CXCL1, and CXCL9 and that this increase was significantly more in mice lacking GC-C (Figure 7). Similarly, lipopolysaccharide binding protein (LBP) was elevated at day 4 p.i. in $\mathrm{GC}^{-\mathrm{C}^{-1-}}$ liver. These data are consistent with initial barrier dysfunction occurring at day 4 p.i. and suggests that intestinal barrier loss and circulation of luminal contents precedes translocation of live bacteria from the gut lumen in these mice. 


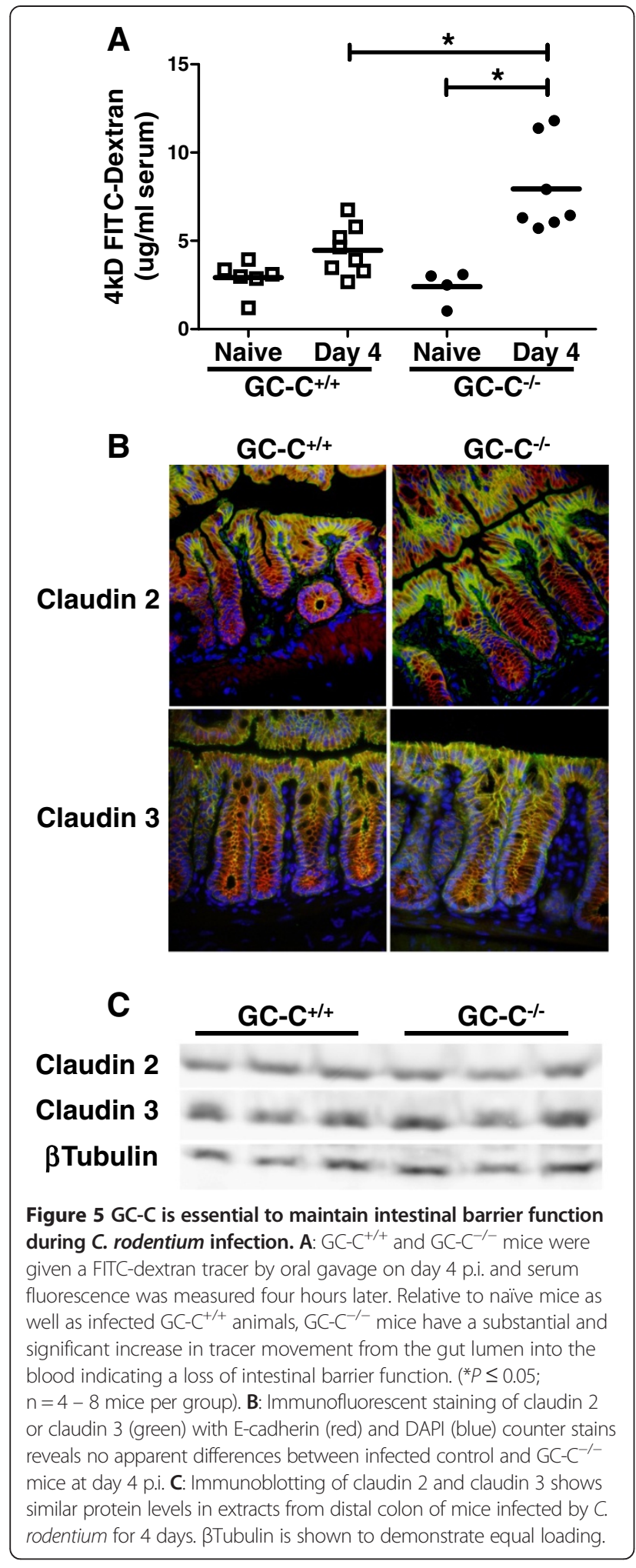

Commensal microflora composition is altered in gut of naïve mice lacking GC-C

Commensal microflora load and diversity are strongly influenced by epithelial ion transport in the intestine

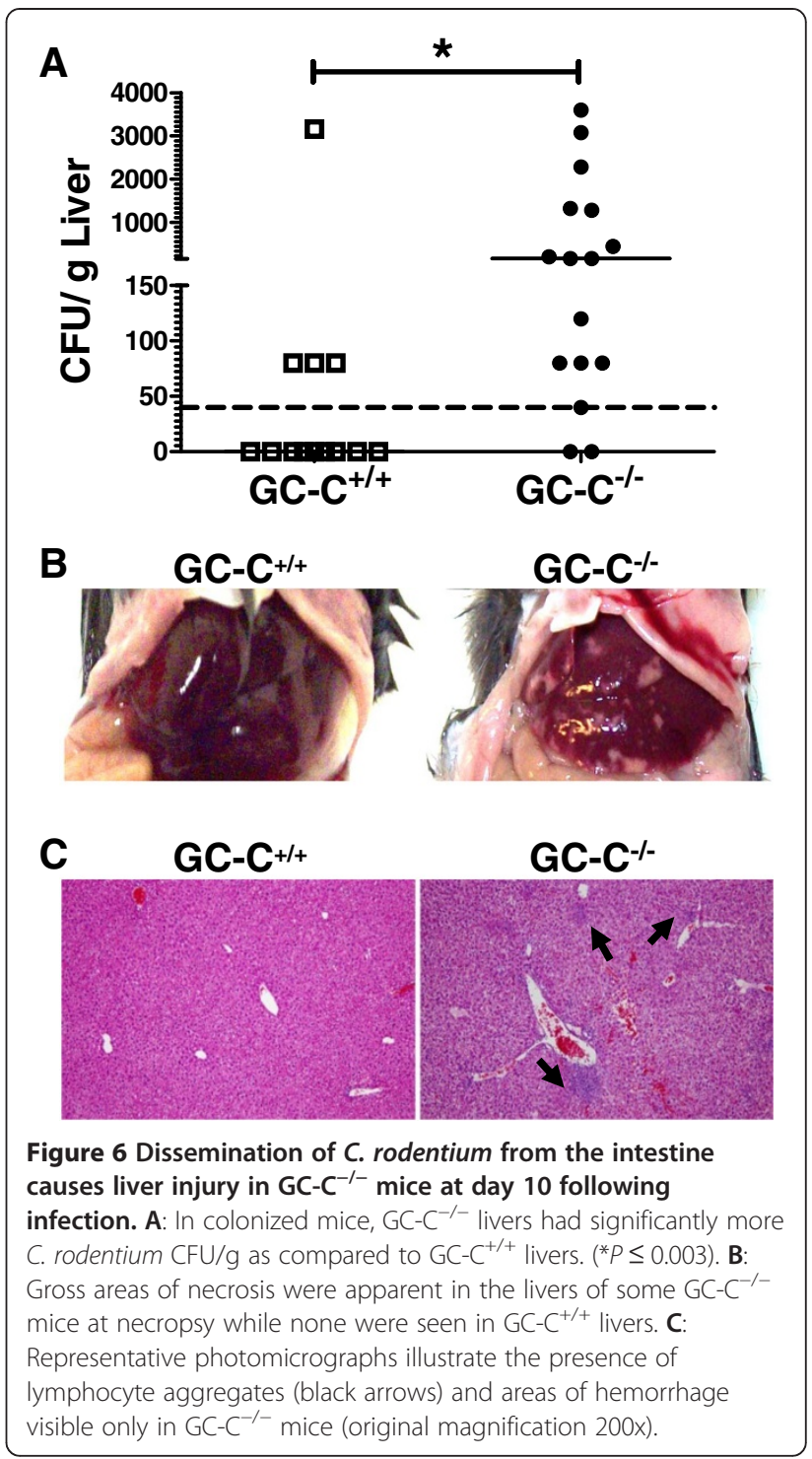

[41-44]. Importantly, the pathogenicity of C. rodentium is affected by the complement of commensal bacteria in the gut $[3,4]$. We therefore used bacterial DNA extracted from stool to monitor any potential differences in bacterial load or composition in naive $\mathrm{GC}-\mathrm{C}^{-/-}$mice compared to $\mathrm{GC}-\mathrm{C}^{+/+}$. Bacterial load was quantified by PCR with universal primers that recognize eubacterial $16 \mathrm{~S}$ ribosomal RNA genes, and then normalized to stool weight. We initially found a statistically significant decrease in stool bacterial load in $\mathrm{GC}-\mathrm{C}^{-/-}$mice $\left(\mathrm{GC}^{-\mathrm{C}^{+/+}}, 2.3 \times 10^{7}\right.$ copies/gram stool vs. GC-C ${ }^{-/-}, 1.0 \times 10^{7}, \mathrm{n}=10-12$, $P \leq 0.002$, Mann Whitney test). We next utilized group and family-specific $16 \mathrm{~S}$ gene primers to assess microflora

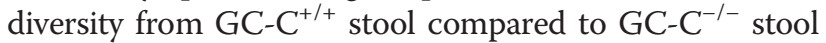
(Figure 8). In stool from $\mathrm{GC}-\mathrm{C}^{-/-}$mice there was increased levels of Enterobacteriacae (1.0 vs. 3.1 fold-change, $\mathrm{GC}^{-\mathrm{C}^{+/+}}$vs. GC-C $\mathrm{C}^{-/-}, \mathrm{P} \leq 0.03$ ) and Atopobium (1.0 vs. 1.5, 

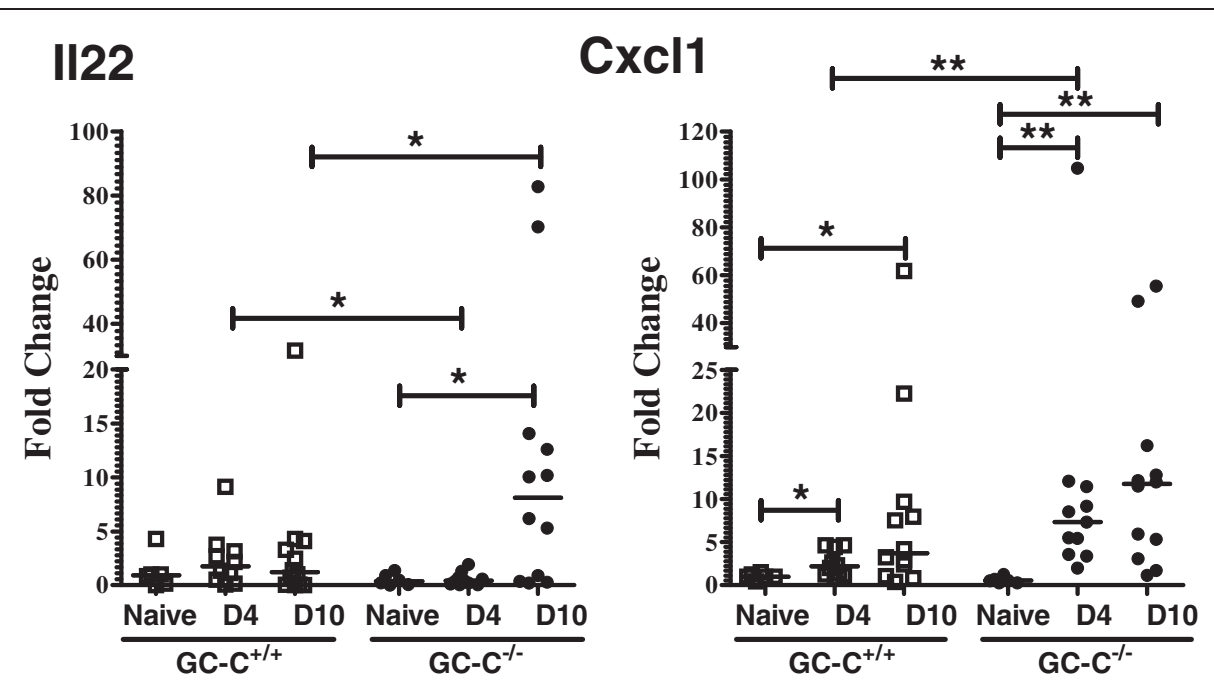

\section{Lbp}

\section{Cxc19}
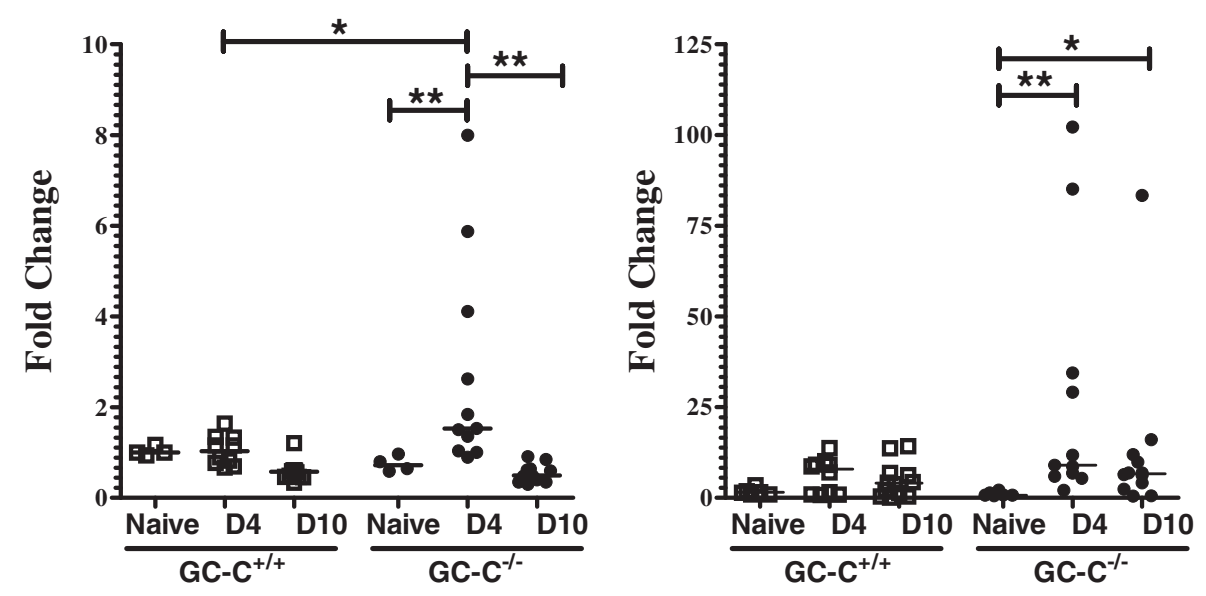

Figure 7 Pro-inflammatory gene expression is enhanced in $\mathrm{GC}-\mathrm{C}^{-/-}$livers at $\mathbf{4}$ and $\mathbf{1 0}$ days post-infection. Real time RT-PCR was used to assess differences in liver gene expression from naive and infected mice at days 4 and 10 p.i. At day 4 , levels of CXCL1, CXCL9, and LBP were increased in liver from GC- $\mathrm{C}^{-/-}$mice. Consistent with the obvious liver damage seen in the GC- $\mathrm{C}^{-/-}$mice at day 10, levels of IL-22, CXCL1, and CXCL9 were significantly elevated. All values are relative to the level in uninfected GC-C ${ }^{+/+}$liver. Line represents median value. $\left({ }^{* *} P \leq 0.005,{ }^{*} P \leq\right.$ $0.05, n=4-10$ mice per group; D4, day 4 p.i.; D10, day 10 p.i.).

$P \leq 0.03)$ as well as decreased presence of the Lactobacillus group (1.0 vs. 0.23 fold-change, $P \leq 0.01$ ) compared to $\mathrm{GC} \mathrm{C}^{+/+}$mice. No differences were found with primers recognizing Bifidobacteria, Eubacterium rectale/Clostridiae cocoides, and the Bacteroides-Prevotella-Porphyromonas group.

\section{Discussion}

Targeting of GC-C by ST results in severe secretory diarrhea and is a significant cause of morbidity and mortality in children of developing countries. It has long been speculated that this GC-C-conferred susceptibility to some forms of enteric infection is offset by a critical role for this receptor in intestinal homeostasis. We and others have suggested that GC-C is important for epithelial ion transport, cell proliferation, and barrier function and that GC-C modulates intestinal disorders ranging from cystic fibrosis to gastrointestinal cancer to intestinal injury and inflammation via these effects $[14,16-18,45]$. Here, we extend the role of GC-C in the intestine by demonstrating that, although it is exploited by ST-producing ETEC, this pathway is highly protective during enteric infection by attaching/effacing bacterial pathogens which do not produce ST toxin. Specifically, we show that GC-C is required to minimize bacterial load during the early to middle phases of $C$. rodentium infection. We also demonstrate that $\mathrm{GC}-\mathrm{C}$ activity is essential for maintaining the integrity of the intestinal epithelial barrier, both by 


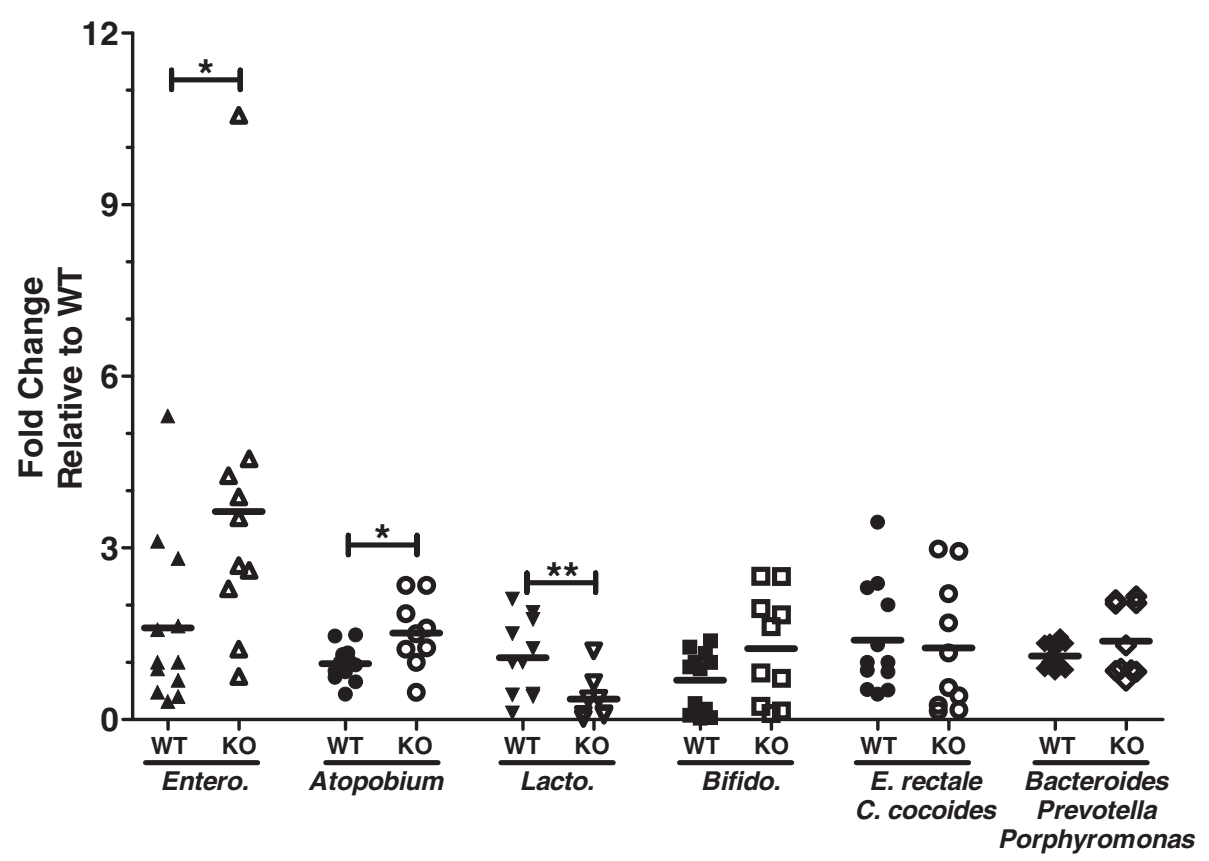

Figure 8 The composition of commensal bacteria is altered in naive GC-C $\mathrm{C}^{-/-}$mice relative to $\mathrm{GC}-\mathrm{C}^{+/+}$. Real time PCR of bacterial genomic DNA extracted from stool was performed using family-specific bacterial $16 \mathrm{~S}$ rRNA gene primers. There was significant enrichment of Enterobacteriaceae and Atopobium in GC- $\mathrm{C}^{-1-}$ compared to GC- $\mathrm{C}^{+/+}$while the level of Lactobacillus was decreased. Line represents median value. (Entero., Enterobacteriaceae; Lacto., Lactobacillus; Bifido., Bifidobacteria; E. rectale, Eubacterium rectale; C. cocoides, Clostridiae cocoides; WT, wildtype $\mathrm{GC}-\mathrm{C}^{+/+} ; \mathrm{KO}, \mathrm{GC}-\mathrm{C}^{-/-} ;{ }^{*} \mathrm{P}<0.03,{ }^{* *} \mathrm{P}<0.005, \mathrm{n}=10-12$ per group).

reducing permeability early in infection as well as by suppressing epithelial apoptosis at later time points. The important role of GC-C in controlling pathogen load and intestinal barrier function is likely instrumental in minimizing systemic dissemination of attaching/ effacing lesion forming bacteria such as $C$. rodentium. Furthermore, we demonstrate several additional novel aspects of epithelial GC-C/cGMP signaling. First, in the context of the C57BL/6 genetic background, infection by attaching/effacing bacteria such as $C$. rodentium does not significantly disrupt intestinal fluid homeostasis in the absence of GC-C. Second, loss of GC-C has no apparent impact on the hyperplasia of epithelial crypts that occurs in response to infection by attaching/effacing bacterial pathogens. Third, Gn expression is profoundly reduced during $C$. rodentium infection and this occurs prior to epithelial hypertrophy or substantial immune cell infiltration. Fourth, $\mathrm{GC}-\mathrm{C}$ regulates the number and composition of intestinal commensal microflora in naïve mice.

Several multifunctional effector proteins (such as EspF and Map) common to C. rodentium and other attaching/effacing pathogens, cause host epithelial cell apoptosis as well as the disruption of intercellular tight junctions [37,46,47]. Bacterial translocation is associated with the intestinal cell death, inflammation, and barrier dysfunction seen during experimental C. rodentium infection $[31,39,48]$. We have previously reported increased radiation-induced intestinal epithelial cell apoptosis and epithelial barrier dysfunction in response to LPS challenge that resulted in translocation of commensal bacteria in $\mathrm{GC}-\mathrm{C}^{-/-}$mice $[16,17]$. In the current study, we show both a loss of barrier integrity in the intestine at early stages of infection and a significant elevation in intestinal epithelial apoptosis in $\mathrm{GC}^{-\mathrm{C}^{-/}}$mice that culminates in translocation of $C$. rodentium out of the intestine. While this correlates with the increased bacterial load in stool from GC-C $\mathrm{C}^{-/-}$at day 10 , it is notable that we did not find major differences in the localization of $C$. rodentium colonization within the colon of ${\mathrm{GC}-\mathrm{C}^{-/-}}^{-}$mice as compared to $\mathrm{GC}-\mathrm{C}^{+/+}$. At day 4, prior to translocation of live bacteria, there was significantly increased intestinal permeability in $\mathrm{GC}^{-\mathrm{C}^{-1}}$ mice and this correlated with elevated expression of chemokine and acute phase genes in the liver as compared to $\mathrm{GC}^{-\mathrm{C}^{+/+}}$. Collectively, this work indicates that GC-C activity is an essential component of epithelial barrier function and anti-apoptosis and is required for multiple aspects of intestinal barrier function during enteric infection.

There is increasing evidence that complex, reciprocal crosstalk between the host and its commensal microflora has a broad and profound impact on gastrointestinal mucosal immunity and is a critical factor in defining susceptibility to cancer, inflammation, obesity as well as infection by bacterial pathogens [49]. Fecal transplant from a C. rodentium-resistant mouse strain reduced mortality in 
a susceptible murine genetic background [3,4]. In addition, treatment with the probiotic bacteria Lactobaccillus promoted survival of $C$. rodentium-infected neonatal mice [50], while exposure to a stressor (physical restraint) both altered gut microbial composition and increased colonization by $C$. rodentium [51]. Many factors shape the influence of commensal microflora on colonization resistance to a pathogen, and may include direct inhibition by bacteriocins (antimicrobials generated by bacteria), bacterial metabolites, or competition for nutrients [49]. Alternatively, the abundance of closely related family members may be indicative of the potential success of a pathogen from the same family with related growth characteristics [52]. Because an imbalance in intestinal microflora often occurs in mice with deregulated ion transport pathways $[41,43]$, we investigated whether this may contribute to the increased $C$. rodentium colonization noted in GC-C $\mathrm{C}^{-/-}$mice. Here, we have demonstrated that loss of GC-C has a significant impact on the abundance and systemic dissemination of an enteric bacterial pathogen and we further show that naïve $\mathrm{GC}-\mathrm{C}^{-/-}$mice have a significant imbalance in intestinal bacterial species relative to their $\mathrm{GC}-\mathrm{C}^{+/+}$counterparts. In addition to a decrease in potentially protective Lactobacillus, the Enterobacteriaceae family colonizes the gut of naive $\mathrm{GC}-\mathrm{C}^{-/-}$mice at higher

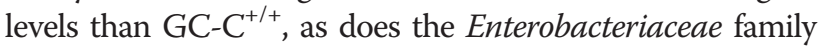
member $C$. rodentium during the early stages of the infection course. It is possible that $\mathrm{GC}-\mathrm{C}$ activity regulates outgrowth of commensal bacteria as well as $C$. rodentium by affecting epithelial mucus layer dynamics, cell surface or luminal $\mathrm{pH}$, or the ion/solute-dependent aspects of bacterial metabolism and growth. Additional studies will be necessary to define the mechanism through which GC-C influences the composition and load of commensal bacteria.

External factors, such as variation in diet and animal husbandry conditions at any given research institute, impact the composition of gut microflora and can have a dominant influence on disease model phenotype [53-55]. Therefore, genetically-modified mice used as models of gastrointestinal pathology such as bacterial infection, inflammation, obesity, and tumor susceptibility reflect the interaction between investigator-imposed genetic modifications and institution- or animal colony-dependent microflora. Further characterization and study of the microbiome of the GC- $\mathrm{C}^{-/-}$intestine will be necessary to establish its specific role in susceptibility to bacterial infection as well as its putative broader impact on gastrointestinal pathophysiology.

\section{Conclusions}

In summary, we have identified a protective role for $\mathrm{GC}-\mathrm{C}$ signaling in defense against an attaching/effacing lesionforming bacterial pathogen. Our studies have shown that
GC-C is required to maintain an effective epithelial barrier and to suppress systemic dissemination of $C$. rodentium. We also demonstrate an imbalance in commensal microflora in naive $\mathrm{GC}-\mathrm{C}^{-/-}$mice relative to $\mathrm{GC}-\mathrm{C}^{+/+}$animals from the same colony and speculate that this is an important component in the increased colonization of enteric pathogens in mice lacking $\mathrm{GC}-\mathrm{C}$.

\section{Abbreviations}

GC-C: Guanylate cyclase 2C, GUCY2C; GN: Guanylin; CFTR: Cystic fibrosis transmembrane conductance regulator; NHE3: $\mathrm{Na}^{+} / \mathrm{H}^{+}$exchanger 3; Cxcl1: Chemokine (C-X-C motif) ligand 1; Cxcl9: Chemokine (C-X-C motif) ligand 9; LBP: Lipopolysaccharide binding protein; LL-22: Interleukin 22.

\section{Competing interests}

The authors affirm that they are not entered in any relationships with any organization or entity having a direct financial or personal interest in the subject matter or materials discussed in the article.

\section{Authors' contributions}

EAM, EHL, and KAS participated in study design, performed experiments and interpreted data. EAM and KAS wrote and edited the paper. MBC contributed essential reagents, participated in study design, and edited the paper. All authors read and approved the final manuscript.

\section{Acknowledgments}

This work was supported by the AGA Foundation for Digestive Health and Nutrition, the Crohn's and Colitis Foundation of America, NIH R01DK047318, and, in part, by PHS Grant DK P30DK078392.

Received: 17 May 2013 Accepted: 21 August 2013

Published: 2 September 2013

\section{References}

1. Mundy R, MacDonald TT, Dougan G, Frankel G, Wiles S: Citrobacter rodentium of mice and man. Cell Microbiol 2005, 7(12):1697-1706.

2. Borenshtein D, Schlieper KA, Rickman BH, Chapman JM, Schweinfest CW, Fox JG, Schauer DB: Decreased expression of colonic Slc26a3 and carbonic anhydrase IV as a cause of fatal infectious diarrhea in mice. Infect Immun 2009, 77(9):3639-3650.

3. Ghosh S, Dai C, Brown K, Rajendiran E, Makarenko S, Baker J, Ma C, Halder S, Montero M, lonescu VA, et al: Colonic microbiota alters host susceptibility to infectious colitis by modulating inflammation, redox status, and ion transporter gene expression. Am J Physiol Gastrointest Liver Physiol 2011, 301(1):G39-G49.

4. Willing BP, Vacharaksa A, Croxen M, Thanachayanont T, Finlay BB: Altering host resistance to infections through microbial transplantation. PLoS One 2011, 6(10):e26988.

5. Currie MG, Fok KF, Kato J, Moore RJ, Hamra FK, Duffin KL, Smith CE: Guanylin: an endogenous activator of intestinal guanylate cyclase. Proc Natl Acad Sci USA 1992, 89(3):947-951.

6. Hamra FK, Forte LR, Eber SL, Pidhorodeckyj NV, Krause WJ, Freeman RH, Chin DT, Tompkins JA, Fok KF, Smith CE, et al: Uroguanylin: structure and activity of a second endogenous peptide that stimulates intestinal guanylate cyclase. Proc Natl Acad Sci USA 1993, 90(22):10464-10468.

7. Chao AC, de Sauvage FJ, Dong YJ, Wagner JA, Goeddel DV, Gardner P: Activation of intestinal CFTR Cl- channel by heat-stable enterotoxin and guanylin via CAMP-dependent protein kinase. EMBO J 1994, 13(5):1065-1072.

8. Seidler U, Blumenstein I, Kretz A, Viellard-Baron D, Rossmann H, Colledge WH, Evans $M$, Ratcliff $R$, Gregor M: A functional CFTR protein is required for mouse intestinal cAMP-, cGMP- and $\mathrm{Ca}(2+)$-dependent $\mathrm{HCO}$ secretion. J Physiol 1997, 505(Pt 2):411-423.

9. Cha B, Kim JH, Hut H, Hogema BM, Nadarja J, Zizak M, Cavet M, Lee-Kwon W, Lohmann SM, Smolenski A, et al: CGMP inhibition of $\mathrm{Na}+/ \mathrm{H}+$ antiporter 3 (NHE3) requires PDZ domain adapter NHERF2, a broad specificity protein kinase G-anchoring protein. J Biol Chem 2005, 280(17):16642-16650. 
10. Schulz S, Green CK, Yuen PS, Garbers DL: Guanylyl cyclase is a heat-stable enterotoxin receptor. Cell 1990, 63(5):941-948.

11. Mann EA, Jump ML, Wu J, Yee E, Giannella RA: Mice lacking the guanylyl cyclase $C$ receptor are resistant to STa-induced intestinal secretion. Biochem Biophys Res Commun 1997, 239(2):463-466.

12. Schulz S, Lopez MJ, Kuhn M, Garbers DL: Disruption of the guanylyl cyclase-C gene leads to a paradoxical phenotype of viable but heat-stable enterotoxin-resistant mice. J Clin Invest 1997, 100(6):1590-1595.

13. Li P, Lin JE, Chervoneva I, Schulz S, Waldman SA, Pitari GM: Homeostatic control of the crypt-villus axis by the bacterial enterotoxin receptor guanylyl cyclase $C$ restricts the proliferating compartment in intestine. Am J Pathol 2007, 171(6):1847-1858.

14. Pitari GM, Di Guglielmo MD, Park J, Schulz S, Waldman SA: Guanylyl cyclase $C$ agonists regulate progression through the cell cycle of human colon carcinoma cells. Proc Natl Acad Sci USA 2001, 98(14):7846-7851.

15. Shailubhai K, Yu HH, Karunanandaa K, Wang JY, Eber SL, Wang Y, Joo NS, Kim HD, Miedema BW, Abbas SZ, et al: Uroguanylin treatment suppresses polyp formation in the $\mathrm{Apc}(\mathrm{Min} /+)$ mouse and induces apoptosis in human colon adenocarcinoma cells via cyclic GMP. Cancer Res 2000 60(18):5151-5157.

16. Han X, Mann E, Gilbert S, Guan Y, Steinbrecher KA, Montrose MH, Cohen $M B$ : Loss of guanylyl cyclase C (GCC) signaling leads to dysfunctional intestinal barrier. PLOS ONE 2011, 6(1):e16139.

17. Garin-Laflam MP, Steinbrecher KA, Rudolph JA, Mao J, Cohen MB: Activation of guanylate cyclase $C$ signaling pathway protects intestinal epithelial cells from acute radiation-induced apoptosis. Am J Physiol Gastrointest Liver Physiol 2009, 296(4):G740-G749.

18. Steinbrecher KA, Harmel-Laws E, Garin-Laflam MP, Mann EA, Bezerra LD, Hogan SP, Cohen MB: Murine guanylate cyclase $C$ regulates colonic injury and inflammation. J Immuno/ 2011, 186(12):7205-7214.

19. Steinbrecher KA, Harmel-Laws E, Sitcheran R, Baldwin AS: Loss of epithelia RelA results in deregulated intestinal proliferative/apoptotic homeostasis and susceptibility to inflammation. J Immunol 2008, 180(4):2588-2599.

20. Berg DJ, Davidson N, Kuhn R, Muller W, Menon S, Holland G, ThompsonSnipes L, Leach MW, Rennick D: Enterocolitis and colon cancer in interleukin-10-deficient mice are associated with aberrant cytokine production and CD4(+) TH1-like responses. J Clin Invest 1996, 98(4):1010-1020

21. Schultz M, Tonkonogy SL, Sellon RK, Veltkamp C, Godfrey VL, Kwon J, Grenther WB, Balish E, Horak I, Sartor RB: IL-2-deficient mice raised under germfree conditions develop delayed mild focal intestinal inflammation. Am J Physiol 1999, 276(6 Pt 1):G1461-G1472.

22. Bergstrom KSB, Kissoon-Singh V, Gibson DL, Ma C, Montero M, Sham HP Ryz N, Huang T, Velcich A, Finlay BB, et al: Muc2 Protects against lethal infectious colitis by disassociating pathogenic and commensal bacteria from the colonic mucosa. PLoS Pathog 2010, 6(5):e1000902

23. Steinbrecher KA, Horowitz NA, Blevins EA, Barney KA, Shaw MA, HarmelLaws E, Finkelman FD, Flick MJ, Pinkerton MD, Talmage KE, et al: Colitisassociated cancer is dependent on the interplay between the hemostatic and inflammatory systems and supported by integrin alpha (M)beta(2) engagement of fibrinogen. Cancer Res 2010, 70(7):2634-2643.

24. Mann EA, Shanmukhappa K, Cohen MB: Lack of guanylate cyclase C results in increased mortality in mice following liver injury. $B M C$ Gastroenterol 2010, 10:86.

25. Walker NM, Simpson JE, Yen PF, Gill RK, Rigsby EV, Brazill JM, Dudeja PK, Schweinfest $\mathrm{CW}$, Clarke LL: Down-regulated in adenoma $\mathrm{Cl} / \mathrm{HCO} 3$ exchanger couples with $\mathrm{Na} / \mathrm{H}$ exchanger 3 for $\mathrm{NaCl}$ absorption in murine small intestine. Gastroenterology 2008, 135(5):1645-1653. e1643.

26. Wei L, Simen A, Mane S, Kaffman A: Early life stress inhibits expression of a novel innate immune pathway in the developing hippocampus. Neuropsychopharmacology 2012, 37(2):567-580

27. Barman M, Unold D, Shifley K, Amir E, Hung K, Bos N, Salzman N: Enteric salmonellosis disrupts the microbial ecology of the murine gastrointestinal tract. Infect Immun 2008, 76(3):907-915.

28. Rinttila T, Kassinen A, Malinen E, Krogius L, Palva A: Development of an extensive set of $16 \mathrm{~S}$ rDNA-targeted primers for quantification of pathogenic and indigenous bacteria in faecal samples by real-time PCR. J Appl Microbiol 2004, 97(6):1166-1177.

29. Ivanov II, Atarashi K, Manel N, Brodie EL, Shima T, Karaoz U, Wei D, Goldfarb KC, Santee CA, Lynch SV, et al: Induction of intestinal Th17 cells by segmented filamentous bacteria. Cell 2009, 139(3):485-498.
30. Maaser C, Housley MP, limura M, Smith JR, Vallance BA, Finlay BB, Schreiber JR, Varki NM, Kagnoff MF, Eckmann L: Clearance of citrobacter rodentium requires $B$ cells but not secretory immunoglobulin a $(\lg A)$ or $\lg M$ antibodies. Infect Immun 2004, 72(6):3315-3324.

31. Spehlmann ME, Dann SM, Hruz P, Hanson E, McCole DF, Eckmann L: CXCR2-Dependent mucosal neutrophil influx protects against colitisassociated diarrhea caused by an attaching/effacing lesion-forming bacterial pathogen. J Immunol 2009, 183(5):3332-3343.

32. Borenshtein D, Fry RC, Groff EB, Nambiar PR, Carey VJ, Fox JG, Schauer DB: Diarrhea as a cause of mortality in a mouse model of infectious colitis. Genome Biol 2008, 9(8):R122.

33. Umar S, Scott J, Sellin JH, Dubinsky WP, Morris AP: Murine colonic mucosa hyperproliferation. I. Elevated CFTR expression and enhanced CAMPdependent $\mathrm{Cl}(-)$ secretion. Am J Physiol Gastrointest Liver Physiol 2000, 278(5):G753-G764

34. Wine E, Shen-Tu G, Gareau MG, Goldberg HA, Licht C, Ngan BY, Sorensen ES, Greenaway J, Sodek J, Zohar R, et al: Osteopontin mediates citrobacter rodentium-induced colonic epithelial cell hyperplasia and attachingeffacing lesions. Am J Pathol 2010, 177(3):1320-1332.

35. Steinbrecher KA, Wowk SA, Rudolph JA, Witte DP, Cohen MB: Targeted inactivation of the mouse guanylin gene results in altered dynamics of colonic epithelial proliferation. Am J Pathol 2002, 161(6):2169-2178

36. Lin JE, Snook AE, Li P, Stoecker BA, Kim GW, Magee MS, Garcia AV, Valentino MA, Hyslop T, Schulz S, et al: GUCY2C Opposes systemic genotoxic tumorigenesis by regulating AKT-dependent intestinal barrier integrity. PLoS One 2012, 7(2):e31686.

37. Guttman JA, Li Y, Wickham ME, Deng W, Vogl AW, Finlay BB: Attaching and effacing pathogen-induced tight junction disruption in vivo. Cell Microbiol 2006, 8(4):634-645.

38. Conlin VS, Wu X, Nguyen C, Dai C, Vallance BA, Buchan AM, Boyer L, Jacobson K: Vasoactive intestinal peptide ameliorates intestinal barrier disruption associated with citrobacter rodentium-induced colitis. Am J Physiol Gastrointest Liver Physiol 2009, 297(4):G735-G750.

39. Zheng Y, Valdez PA, Danilenko DM, Hu Y, Sa SM, Gong Q, Abbas AR, Modrusan Z, Ghilardi N, de Sauvage FJ, et al: Interleukin-22 mediates early host defense against attaching and effacing bacterial pathogens. Nat Med 2008, 14(3):282-289.

40. Raczynski AR, Muthupalani S, Schlieper K, Fox JG, Tannenbaum SR, Schauer DB: Enteric infection with citrobacter rodentium induces coagulative liver necrosis and hepatic inflammation prior to peak infection and colonic disease. PLoS One 2012, 7(3):e33099.

41. De Lisle RC: Altered transit and bacterial overgrowth in the cystic fibrosis mouse small intestine. Am J Physiol Gastrointest Liver Physiol 2007, 293(1):G104-G111

42. Laubitz D, Larmonier CB, Bai A, Midura-Kiela MT, Lipko MA, Thurston RD, Kiela PR, Ghishan FK: Colonic gene expression profile in NHE3-deficient mice: evidence for spontaneous distal colitis. Am J Physiol Gastrointest Liver Physiol 2008, 295(1):G63-G77.

43. Norkina O, Burnett TG, De Lisle RC: Bacterial overgrowth in the cystic fibrosis transmembrane conductance regulator null mouse small intestine. Infect Immun 2004, 72(10):6040-6049.

44. Keely S, Kelly C, Weissmueller T, Burgess A, Wagner B, Robertson CE, Harris $\mathrm{JK}$, Colgan SP: Activated fluid transport regulates bacterial-epithelial interactions and significantly shifts the murine colonic microbiome. Gut Microbes 2012, 3(3):250-260.

45. Steinbrecher KA, Cohen MB: Transmembrane guanylate cyclase in intestinal pathophysiology. Curr Opin Gastroenterol 2011, 27(2):139-145.

46. Ma C, Wickham ME, Guttman JA, Deng W, Walker J, Madsen $\mathrm{KL}$, Jacobson $\mathrm{K}$, Vogl WA, Finlay BB, Vallance BA: Citrobacter rodentium infection causes both mitochondrial dysfunction and intestinal epithelial barrier disruption in vivo: role of mitochondrial associated protein (Map). Cell Microbiol 2006, 8(10):1669-1686.

47. Holmes A, Muhlen S, Roe AJ, Dean P: The EspF effector, a bacterial pathogen's swiss army knife. Infect Immun 2010, 78(11):4445-4453.

48. Vallance BA, Deng W, Jacobson K, Finlay BB: Host susceptibility to the attaching and effacing bacterial pathogen citrobacter rodentium. Infect Immun 2003, 71(6):3443-3453.

49. Stecher B, Hardt WD: Mechanisms controlling pathogen colonization of the gut. Curr Opin Microbiol 2011, 14(1):82-91. 
50. Gareau MG, Wine E, Reardon C, Sherman PM: Probiotics prevent death caused by citrobacter rodentium infection in neonatal mice. J Infect Dis 2010, 201(1):81-91.

51. Bailey MT, Dowd SE, Parry NMA, Galley JD, Schauer DB, Lyte M: Stressor exposure disrupts commensal microbial populations in the intestines and leads to increased colonization by citrobacter rodentium. Infect Immun 2010, 78(4):1509-1519.

52. Stecher B, Chaffron S, Kappeli R, Hapfelmeier S, Freedrich S, Weber TC, Kirundi J, Suar M, McCoy KD, von Mering C, et al: Like will to like: abundances of closely related species can predict susceptibility to intestinal colonization by pathogenic and commensal bacteria. PLoS Pathog 2010, 6(1):e1000711.

53. Friswell MK, Gika H, Stratford IJ, Theodoridis G, Telfer B, Wilson ID, McBain $\mathrm{AJ}$ : Site and strain-specific variation in gut microbiota profiles and metabolism in experimental mice. PLoS One 2010, 5(1):e8584.

54. Gill N, Finlay BB: The gut microbiota: challenging immunology. Nat Rev Immunol 2011, 11(10):636-637.

55. Ubeda C, Lipuma L, Gobourne A, Viale A, Leiner I, Equinda M, Khanin R, Pamer EG: Familial transmission rather than defective innate immunity shapes the distinct intestinal microbiota of TLR-deficient mice. J Exp Med 2012, 209(8):1445-1456.

doi:10.1186/1471-230X-13-135

Cite this article as: Mann et al: Guanylate cyclase C limits systemic dissemination of a murine enteric pathogen. BMC Gastroenterology 2013 13:135.

\section{Submit your next manuscript to BioMed Central and take full advantage of:}

- Convenient online submission

- Thorough peer review

- No space constraints or color figure charges

- Immediate publication on acceptance

- Inclusion in PubMed, CAS, Scopus and Google Scholar

- Research which is freely available for redistribution 